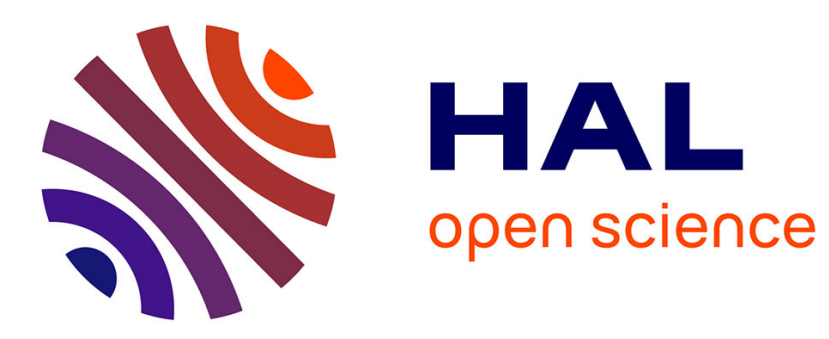

\title{
Vicarious Shame and Guilt
}

Brian Lickel, Toni Schmader, Mathew Curtis, Marchelle Scarnier, Daniel R.

Ames

\section{To cite this version:}

Brian Lickel, Toni Schmader, Mathew Curtis, Marchelle Scarnier, Daniel R. Ames. Vicarious Shame and Guilt. Group Processes and Intergroup Relations, 2005, 8 (2), pp.145-157. 10.1177/1368430205051064 . hal-00571599

\section{HAL Id: hal-00571599 \\ https://hal.science/hal-00571599}

Submitted on 1 Mar 2011

HAL is a multi-disciplinary open access archive for the deposit and dissemination of scientific research documents, whether they are published or not. The documents may come from teaching and research institutions in France or abroad, or from public or private research centers.
L'archive ouverte pluridisciplinaire HAL, est destinée au dépôt et à la diffusion de documents scientifiques de niveau recherche, publiés ou non, émanant des établissements d'enseignement et de recherche français ou étrangers, des laboratoires publics ou privés. 


\title{
Vicarious Shame and Guilt
}

\author{
Brian Lickel \\ University of Southern California
}

Toni Schmader

The University of Arizona

Mathew Curtis

University of Southern California

\section{Marchelle Scarnier}

The University of Arizona

\section{Daniel R. Ames}

Columbia University

\begin{abstract}
Participants recalled instances when they felt vicariously ashamed or guilty for another's wrongdoing and rated their appraisals of the event and resulting motivations. The study tested aspects of social association that uniquely predict vicarious shame and guilt. Results suggest that the experience of vicarious shame and vicarious guilt are distinguishable. Vicarious guilt was predicted by one's perceived interdependence with the wrongdoer (e.g. high interpersonal interaction), an appraisal of control over the event, and a motivation to repair the other person's wrongdoing. Vicarious shame was predicted by the relevance of the event to a shared social identity with the wrongdoer, an appraisal of self-image threat, and a motivation to distance from the event. Implications for intergroup behavior and emotion are discussed.
\end{abstract}

KEYWORDS guilt, interdependence, shame, social identity, stereotypes

I envied other students back then [in postwar Germany] who had dissociated themselves from their parents and thus from the entire generation of perpetrators, voyeurs, and the willfully blind, accommodators and accepters, thereby overcoming perhaps not their shame, but at least their suffering because of the shame (p. 171). (Bernhard Schlink, The Reader)

SHAME and guilt are powerful emotions of selfcondemnation that are thought to regulate social interactions in situations where one has violated a moral or social code (Baumeister,
Stillwell, \& Heatherton, 1995; Eisenberg, 2000; Keltner \& Harker, 1998; Tangney \& Fischer, 1995). Although we commonly think of shame and guilt as feelings we experience as a result of our own actions, the above quotation suggests

\section{Author's note}

Address correspondence to Brian Lickel, Department of Psychology, University of Southern California, Los Angeles, CA 90089, USA [email: lickel@usc.edu] 
that feelings of self-condemnation can sometimes result from acts committed by others. Given that the emotional reactions that we have to the wrongdoings of other group members are relevant to both intragroup and intergroup relations, it is surprising that no theoretical framework has been developed of the antecedents and consequences to distinguish vicarious shame and guilt. The importance of drawing such distinctions is critical if one assumes that each emotion will have unique behavioral consequences: as we will describe, guilt may elicit more approach related behaviors designed to repair the situation, whereas shame may elicit more withdrawing behaviors designed to distance oneself from the situation.

Although the factors that distinguish vicarious shame and guilt have not been empirically investigated, some theorists have suggested that these emotions can be experienced for another's misdeeds (Morris, 1987; Ortony, Clore, \& Collins, 1988; Tangney \& Fischer, 1995; Weiner, 1986). Intergroup researchers, meanwhile, have examined guilt reactions to ingroup bias (e.g. Doosje, Branscombe, Spears, \& Manstead, 1998; Iyer, Leach, \& Crosby, 2003; McGarty et al., in press). Doosje et al. (1998), for example, showed that under certain conditions, Dutch students feel guilty for their country's past history of colonization in Indonesia, and perhaps as a consequence, feel motivated to provide reparations to the people of Indonesia. Furthermore, research on the black sheep effect (e.g. Eidelman \& Biernat, 2003; Marques, Yzerbyt, \& Leyens, 1988) suggests that individuals derogate group members who fail to comply with the norms of the group. This past research demonstrates that people have emotional and behavioral reactions to the negative behaviors of ingroup members. However, because none of this research has examined both shame and guilt, the conclusions yielded about the general nature of vicarious emotion are limited. The goal of the present paper was to test a model that distinguishes between vicarious shame and guilt felt for another's wrongdoing. Rather than focus on one particular type of group in one type of context, our model is intended to generalize to a variety of groups and situations.

\section{The nature of shame and guilt}

Traditional emotion research has often assumed that shame and guilt are more similar than different (e.g. C. A. Smith \& Ellsworth, 1985). However, more contemporary perspectives argue that these two emotions differ in terms of the motivations they evoke and their associated appraisals (e.g. Hong \& Chiu, 1992; Niedenthal, Tangney, \& Gavanski, 1994; R. H. Smith, Webster, Parrott, \& Eyre, 2002; Tangney, Miller, Flicker, \& Barlow, 1996; Wicker, Payne, \& Morgan, 1983). For example, guilt predicts approach-related responses meant to repair the damage that was caused by the guilt-eliciting event, and in fact several studies indicate that guilt is particularly linked to a desire to confess, apologize, or atone for one's own wrongdoings (e.g. Tangney et al., 1996; Wicker et al., 1983). Shame, on the other hand, appears to be more strongly linked to responses aimed at insulating oneself from negative evaluation. Thus, rather than facilitating reparative actions, feelings of shame provoke a desire to hide, disappear, or escape (Tangney, 1995; Wicker et al., 1983).

In addition to being distinguished by their correspondent motivations, shame and guilt also seem to differ with respect to how an individual interprets a transgression with respect to the self (Tangney \& Fischer, 1995). Feeling guilty for one's own wrongdoing is often associated with a focus on the specific controllable behaviors that led up to the wrongful event, whereas feeling ashamed involves a more global emphasis on what that event seems to imply about the dispositional qualities one possesses (Tangney \& Fischer, 1995; Wicker, et al., 1983). For example, individuals who recall a guilt experience are more likely to have the counterfactual thought, 'If only I had acted differently', whereas those who recall a shame experience are more likely to think, 'If only I were a different type of person' (Niedenthal et al., 1994). Similarly, individuals perceive that they have more control over situations that they recall as guilt experiences as compared to shame experiences (Wicker et al., 1983). Shame, however, in comparison to guilt, involves a greater feeling of self-consciousness and a fear 
that one will be rejected by others (R. H. Smith et al., 2002; Tangney et al., 1996; Wicker et al., 1983).

\section{Vicarious shame and guilt}

Given the dominant conceptualization of shame and guilt as self-conscious emotions, it is not surprising that existing research has focused almost exclusively on people's experience of these emotions after they have committed a blameworthy action themselves. Indeed, previous research suggests that shame and guilt are unique among negative emotions in that both typically involve high appraisals of personal responsibility for a negative event (Manstead \& Tetlock, 1989; C. A. Smith \& Ellsworth, 1985). Our work is a departure from this past research in that we suggest that actual personal causality for a negative event is not necessary to experience shame or guilt. We use the terms vicarious shame and guilt to refer to instances in which a person who is not the proximal agent of a wrongdoing experiences these emotions.

Our basic premise, that the emotional lives of individuals are shaped by their association with others, is a premise shared with many prior researchers (e.g. Mackie, Devos, \& Smith, 1999; E. R. Smith, 1993). For example, social psychologists have examined how people 'pick up' and experience the same emotion of those with whom they are in close physical proximity (e.g. Hatfield, Cacioppo, \& Rapson, 1994; Miller, 1987), as well as how people may experience positive and negative feelings as a result of their social identity or association with successful or unsuccessful others (e.g. Cialdini \& de Nicholas, 1989; Tajfel \& Turner, 1986; Tesser, 1988) or may experience vicarious dissonance from the acts of others (Norton, Monin, Cooper, \& Hogg, 2003.) At a basic level, we agree with others who have suggested that our social groups are included as part of our self-identity (e.g. E. R. Smith \& Henry, 1996), and thus the behaviors and attributes of other group members have implications for the self. Much of the existing theory and research on how individuals are affected by their groups presumes that the impact of the group on the self will be greater to the extent that one's association to the group is strong. In fact, there is some evidence that vicarious shame and guilt reactions are stronger in China, a collectivist culture, than in the United States, an individualist culture (Stipek, 1998).

However, a consideration of associationstrength alone does not lead to predictions about the degree to which shame versus guilt is likely to occur. Given the appraisals that are proposed to distinguish shame from guilt experiences, we considered whether there were distinct aspects of social association that might be linked to appraisals of behavioral control over the wrongdoer (thus evoking vicarious guilt) versus appraisals that the event is a threat to one's image (thus evoking vicarious shame). Drawing upon group theory and research (e.g. Brewer, 2000; Hamilton, Sherman, \& Lickel, 1998; Krech \& Crutchfield, 1948; Lewin, 1948; Prentice, Miller, \& Lightdale, 1994; Rabbie \& Horwitz, 1988; Tönnies, 1998; Wilder \& Simon, 1998), we highlight two dimensions of social associations that might play a role in activating these appraisals in response to another's wrongdoing. One dimension is the extent to which individuals are associated by a sense of shared identity. The second dimension is the extent to which individuals are associated by being interpersonally interdependent with one another. Past research, such as Prentice et al., 1994, assumed that these two dimensions might refer to distinct types of groups (which they contrasted as common identity versus common bond groups). In our analysis, we assume that some degree of interpersonal interdependence and some degree of shared identity are present in any social association. Thus, we view these as dimensions, rather than types, of social association.

The term 'shared identity' is used to refer to the degree to which a social association is perceived to reflect a deep and immutable aspect of identity that is common to two or more people and is often used by social perceivers to make causal inferences about their behavior. People may sometimes feel a sense of shared identity with others based on only minimal features (e.g. Tajfel, 1970). However, groups 
based on shared gender, ethnicity, religion, and kinship often seem to involve high levels of shared identity perhaps because these attributes are often seen as essential features of the individual (e.g. Allport, 1954; Haslam, Rothschild, \& Ernst, 2000; Hirschfeld, 1995; Rothbart \& Taylor, 1992; Yzerbyt, Rocher, \& Schadron, 1997). Because perceptions of a shared social identity are a source of self-identification and esteem, people are invested in maintaining a positive reputation of their social identities and are loath to have negative stereotypes about their groups confirmed (Tajfel \& Turner, 1986).

Distinct from the shared identity of a group, 'interpersonal interdependence' refers to the degree to which individuals are perceived to have high levels of social interaction, possess joint goals, and have shared norms of behavior (e.g. Gaertner \& Shopler, 1998, Hinsz, Tindale, \& Vollrath, 1997; Lewin, 1948; Lickel et al., 2000; Rabbie \& Horwitz, 1988; Wilder \& Simon, 1998). An important aspect of interdependent associations is that the associated persons have the opportunity for shared communication and influence over one another's thoughts and behaviors. Examples of highly interdependent associations include business partners, close friends, and sports teammates. Thus, highly interdependent associations involve close contact and communication between individuals, although any other connection between them might be arbitrary. Strong identity-based associations involve stable aspects of perceived similarity among individuals although those individuals may or may not have highly interdependent relationships with one another.

We argue that these different dimensions of association are important to understanding the degree to which a person feels vicarious shame or vicarious guilt because of another's transgression. When an individual engages in some wrongful behavior, one's perceptions of interdependence with that person are hypothesized to be associated with one's appraisals of having control over the occurrence of the event, which in turn are associated with the degree of guilt and reparative motivations. In contrast, the degree to which the person's behavior is seen as relevant to a group identity or reputation shared in common with the perpetrator should relate to an appraisal that the event is a threat to one's own self-image, which in turn should be associated with the degree of shame and distancing motivations. We should make clear that, in some cases, there is a high level of both interdependence with the wrongdoer and a sense that the behavior reflects negatively on a shared identity. In such cases, people may feel both shame and guilt for the group member's actions. As an extreme example, we might imagine that the parents of a high school student who takes a gun to school and kills several classmates might feel guilty because they believe that they should have known about and been able to prevent their child's behavior, whereas they might feel ashamed because they fear that their own 'flesh and blood' is morally flawed. However, though shame and guilt may co-occur, we believe that even in these instances, the emotions are separable.

The present study was designed to test the hypotheses described above. The goal of this study was to disentangle shame- and guiltrelated constructs by assessing people's experiences with multiple group memberships in which there is likely to be some variation in the perception of shared identity as well as interdependence. In particular, we selected three group memberships that, based on past research (e.g. Haslam et al., 2000; Lickel et al., 2000), we expected would differ in their degree of interdependence and shared identity. Specifically, family and friendship groups should be fairly high in interdependence compared to ethnic groups. Furthermore, although all three groups might involve some degree of shared identity, we thought that a sense of shared identity (particularly, an essentialized identity) was more typical of family and ethnic associations than of friendship groups. Participants recalled a time when a member of each of these groups did something that made them (the participants) feel ashamed or guilty. We examined the degree to which variation in their ratings of interdependence and the relevance of the event to a shared identity predicted their appraisals of the event, their emotional reactions, and their behavioral motivations. 


\section{Methods}

\section{Participants and procedures}

Participants were 187 undergraduate students who participated for course credit. Participants were asked to recall and make ratings of three distinct events in which they felt ashamed or guilty for the actions of a family member, a friend, and a person who they do not know well but who happened to share their ethnicity (order was counterbalanced across participants). Participants were instructed to spend five minutes writing about the event and to describe what happened, who did what, and how the event made them feel. Of the 187 participants, 22 were excluded because one or more of the three events recalled was coded as being self-caused, rather than caused by someone else. Thus, responses of 165 participants were analyzed. After each event, participants completed ratings of their emotions, motivations, appraisals, and association related variables.

\section{Measures}

Shame and guilt ratings Participants' emotional reactions to each event were assessed with 23 emotion words (rated from $1=$ Not at all, $9=$ Very intensely). Factor analyses of these emotions utilizing maximum likelihood estimation with varimax rotation yielded distinct clusters of shame and guilt emotions that were consistent across each of the target groups (family, friend, ethnicity). On the basis of these factor analyses, we created separate composites of guilt items (guilty, regret, remorse) and shame items (ashamed, embarrassed, disgraced, and humiliated) for each event. The guilt composite $(\alpha=$ .76 for family, $\alpha=.76$ for friend, $\alpha=.76$ for ethnic group) and the shame composite $(\alpha=$ .82 for family, $\alpha=.78$ for friend, $\alpha=.82$ for ethnic group) were reliable for all three events. Other emotions were included as fillers; results for these emotions can be obtained from the first author.

Appraisals and motivations Behavioral control was assessed with four items: 'I could have prevented this event from occurring', 'I felt I should have done something to prevent the event', 'I'm afraid I may have encouraged the person to do what they did by something I did or said', and 'I felt responsible for the event occurring'. The measure of image threat was assessed with three items 'I felt that the event reflected poorly on me', 'I felt that people would make judgments about the type of person I am based on the event', 'I was afraid that this person's behavior would be viewed as indicating something about the person I am'. Distancing was assessed with three items, 'I wanted to be completely unassociated with the person who caused the event', 'I felt like I wanted to disappear from the situation', and 'At the time, I remember thinking that I didn't want to be associated in any way with the person who caused the event'. Reparative motivations were assessed four items, 'I tried to do something after the event to make it better', 'I felt I should do something after the event to make it better', 'I had a lot of ability to repair the impact of the event after it occurred', and 'I felt I should apologize for what happened'. All items were rated from 1 (strongly disagree) -9 (strongly agree).

A factor analysis using maximum likelihood estimation with varimax rotation yielded a fourfactor solution for each of the groups (family, friend, ethnic group) indicating that items designed to assess behavioral control, image threat, event repair, and distancing were distinct constructs. With some variation, these measures were fairly reliable across target group: behavioral control ( $\alpha=.62$ for family, $\alpha$ $=.57$ for friend, $\alpha=.62$ for ethnic group); image threat $(\alpha=.82$ for family, $\alpha=.81$ for friend, $\alpha=.83$ for ethnic group); reparations ( $\alpha$ $=.78$ for family, $\alpha=.83$ for friend, $\alpha=.78$ for ethnicity); and distancing ( $\alpha=.87$ for family, $\alpha$ $=.84$ for friend, $\alpha=.73$ for ethnicity).

Association related variables Interdependence and shared identity questions were examined via factor analyses with maximum likelihood estimation and varimax rotation. For all three events, items designed to assess interdependence and shared identity fell on two distinct factors. Perceived interdependence was assessed 
with three questions rated on a 9-point scale $(\alpha$ $=.68$ for family, $\alpha=.78$ for friend, $\alpha=.86$ for ethnicity): 'To what degree is the person who caused the event someone that you interact with', 'To what degree do you have influence or control over this person and his/her behavior', and 'How well do you know the person who caused the event?' Identity relevance was assessed by two items 'I felt like this person's behavior was confirming negative conceptions that other people might have about the reputation of my family [or friendship group, or ethnic group]', and 'Was the event at all related to people's negative beliefs or preconceptions about the reputation of your family [or friendship group, or ethnic group]?' (rated on a 9-point scale, 1 $=$ no, $9=$ yes $)$ that were fairly reliable $(\alpha=.66$ for family; $\alpha=.52$ for friends; $\alpha=.60$ for ethnicity).

\section{Results}

\section{Descriptive statistics on variables}

Table 1 is a summary of mean ratings for each of the three target groups and results of oneway repeated analyses of variance (ANOVAs) testing differences among the three groups. These descriptive statistics revealed significant variation among ratings for the three different groups. For example, events involving either family or friends had higher ratings of interdependence, appraisals of control, feelings of guilt, and a desire to make repairs compared to events involving an ethnic ingroup member. Events involving an ethnic ingroup member, in contrast, were rated as highly relevant to the group identity and evoked a desire to distance oneself from the situation.

\section{Hierarchical linear modeling analyses}

Although the mean differences described above are informative, our more specific intention was that by asking participants to rate three different groups, we would have created variance in ratings of interdependence and the potential for the event to be relevant to a shared identity that should be predictive of variance in their ratings of other shame and guilt related constructs in our model. However, because each participant rated three different groups, their ratings were not independent of one another (i.e. ratings of group were nested within subject). To account for the lack of independence in participants' ratings, we used hierarchical linear modeling (HLM; Raudenbush, Bryk, \& Congdon, 2000) to test the hypothesized relationships among the variables in the model nested at the within-subject level. In the

Table 1. Mean ratings in main study variables for each of the three target groups

\begin{tabular}{|c|c|c|c|c|}
\hline & \multicolumn{4}{|c|}{ Target group } \\
\hline & Family & Friend & Ethnicity & One-way ANOVA \\
\hline \multicolumn{5}{|l|}{ Association variables } \\
\hline Identity relevance & 5.08 & $4.87_{\mathrm{a}}$ & $6.39_{\mathrm{b}}$ & $F(2,328)=28.76, p<.001$ \\
\hline Interdependence & $6.48_{\mathrm{a}}$ & $6.10_{\mathrm{a}}$ & $2.19_{\mathrm{b}}$ & $F(2,328)=311.27, p<.001$ \\
\hline \multicolumn{5}{|l|}{ Emotion ratings } \\
\hline Shame & $6.35_{\mathrm{a}}$ & $5.71_{b}$ & $5.66_{\mathrm{b}}$ & $F(2,328)=4.21, p<.05$ \\
\hline Guilt & $3.94_{\mathrm{a}}$ & $3.99_{\mathrm{a}}$ & $3.54_{\mathrm{b}}$ & $F(2,328)=10.87, p<.001$ \\
\hline \multicolumn{5}{|l|}{ Appraisal ratings } \\
\hline Image Threat & $5.56_{\mathrm{a}}$ & $5.63_{\mathrm{a}}$ & $5.07_{\mathrm{b}}$ & $F(2,328)=4.23, p<.05$ \\
\hline Control & $3.17_{\mathrm{b}}$ & $3.73_{\mathrm{a}}$ & $2.21_{c}$ & $F(2,328)=42.57, p<.001$ \\
\hline \multicolumn{5}{|l|}{ Motivation ratings } \\
\hline Distancing & $5.49 \mathrm{a}$ & $5.63_{\mathrm{a}, \mathrm{b}}$ & $6.14_{\mathrm{b}}$ & $F(2,328)=4.18, p<.05$ \\
\hline Repair & $4.64 \mathrm{a}$ & $4.75_{\mathrm{a}}$ & $3.59_{\mathrm{b}}$ & $F(2,328)=18.82, p<.01$ \\
\hline
\end{tabular}

Notes: Means within row not sharing the same subscript differ significantly $(p<.05)$. Response scales ranged from 1 to 9 . 
following analyses, each variable was standardized (z-scored) and entered (person centered) as predictor or outcome variables in a hierarchical maximum likelihood estimation procedure. For these analyses, models were specified with a random error term for predictor variables when analysis of variance components revealed significant variability. The resulting standardized scores are comparable to standardized regression coefficients in leastsquares regression techniques. Relationships from this series of analyses are summarized in Figure 1.
Appraisal, emotion, and motivation results Initial analyses demonstrated that ratings of shame and guilt were somewhat related $(\gamma=.37$, $p<.001)$; as were appraisals of behavioral control and image threat $(\gamma=.16, p<.05)$; while distancing and repair motivations were not $(\gamma=.06, p>.10)$. Next, models were tested in which behavioral control and image threat appraisals were entered simultaneously as predictors first of shame, then of guilt. These analyses supported our predictions that image threat $(\gamma=.39, p<.001)$, rather than behavioral control $(\gamma=.04, p>.10)$, predicts shame,

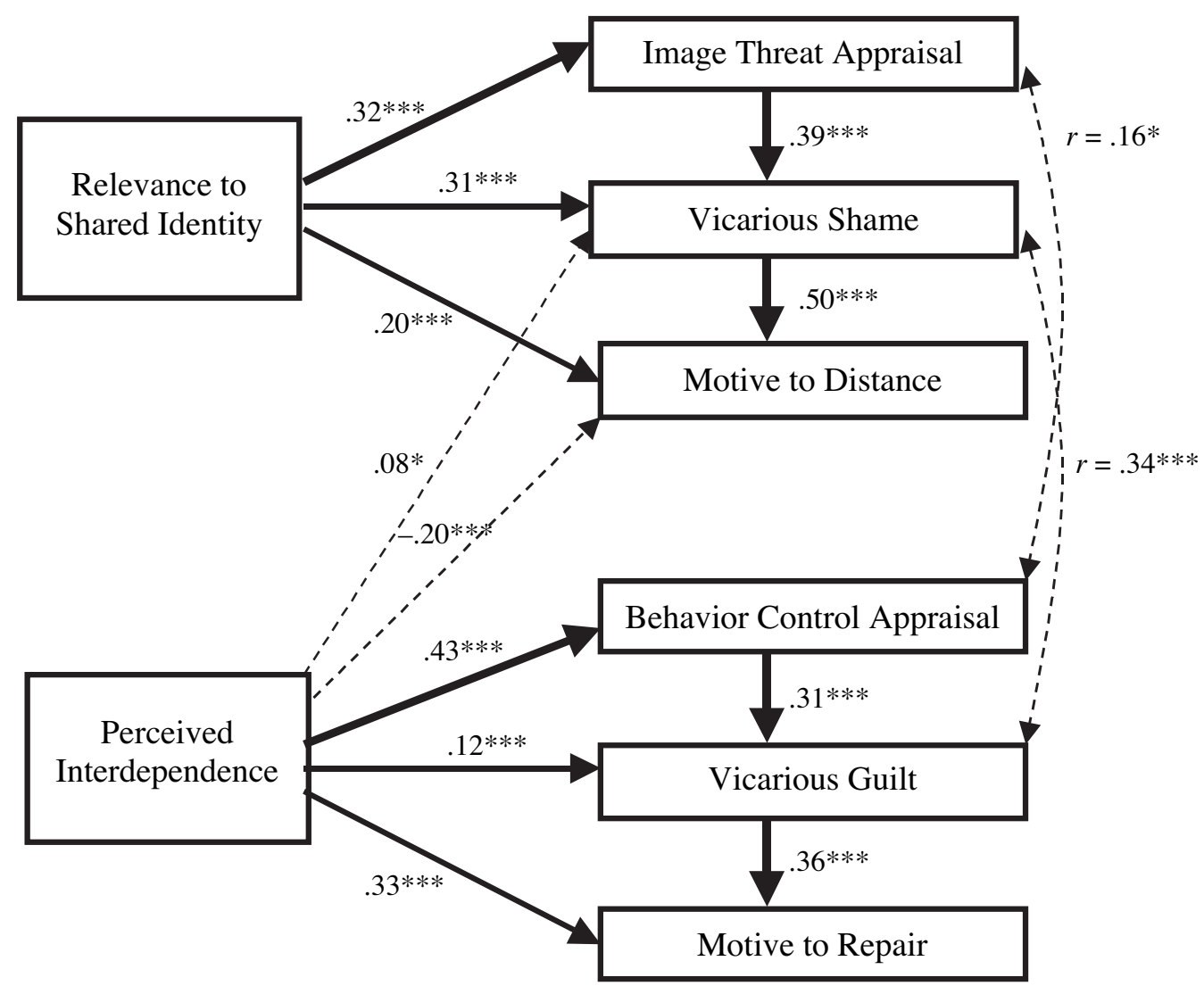

Figure 1. Summary of a series of hierarchical linear modeling analyses testing the relationships among variables (Note: Hypothesized relationships are indicated by solid lines. The implied model was not tested in its entirety simultaneously and is presented for its heuristic value of concisely summarizing relevant results). 
whereas behavioral control $(\gamma=.31, p<001)$, but not image threat $(\gamma=.10, p>.10)$, predicts guilt. In a second pair of analyses, shame and guilt were entered simultaneously as predictors first of distancing, then of repairs. Consistent with past work on self-caused shame and guilt, distancing was uniquely predicted by shame $(\gamma=.50, p<.001)$, but not guilt $(\gamma=-.01$, $p>.10)$. Repair was predicted by guilt $(\gamma=.36$, $p<.001)$, but only weakly by shame $(\gamma=.11$, $p=.07$ ) (a follow-up contrast of the coefficients in HLM indicates that the coefficients for guilt and shame were significantly different, $p<.05$.) Taken together, these results support the notion that there are two distinct profiles of appraisal, emotion, and motivation that distinguish experiences of vicarious shame from experiences of vicarious guilt.

Social association variables as predictors of shame and guilt related constructs We next examined the degree to which interpersonal interdependence and the relevance of the event to social identity uniquely predicted these two emotion profiles. Importantly, an initial analysis showed that perceptions of identity relevance and interdependence were orthogonal $(\gamma=-.03, p>.10)$. The first set of analyses, in which the two association variables were entered as predictors of appraisals, confirmed that identity relevance was a significant predictor of image threat $(\gamma=.32, p<.001)$, but interdependence was not $(\gamma=.05, p>.10)$. Furthermore, interdependence predicted behavioral control $(\gamma=.43, p<.001)$, but identity relevance did not $(\gamma=.05, p>.10)$.

Separate HLM analyses revealed that identity relevance was a stronger predictor of shame $(\gamma=.31, p<.001$, than was interdependence $(\gamma=.08, p<.05)$ (a follow-up contrast of the coefficients in HLM indicates that the coefficients for identity relevance and interdependence were significantly different, $p=.052$ ). In contrast, interdependence was a significant predictor of guilt $(\gamma=.12, p<.001)$, but identity relevance was not $(\gamma=-.05, p>.10)$. Finally, a third set of analyses revealed that identity relevance had a positive relationship to distancing $(\gamma=.20, p<.001)$, whereas interdependence had a negative relationship to distancing $(\gamma=$ $-20, p<.001)$. Interdependence was, as hypothesized, a predictor of repairs $(\gamma=.33, p<.001)$, but identity relevance was not $(\gamma=.04, p>.10)$.

To summarize, the preceding analyses each examined the relationship of people's perceptions of the identity relevance of the event and their interdependence to the wrongdoer to each of the other variables in our framework. Consistent with our model, ratings of identity relevance (and not interdependence) positively predicted shame related constructs, whereas ratings of interdependence (and not identity relevance) positively predicted guilt related constructs.

\section{Discussion}

The results of this study provide support for our hypothesis that vicarious shame and guilt are distinct emotional reactions predicted by unique appraisals of events and by different aspects of one's association to a wrongdoer. People felt guilty for another's wrongdoing to the extent that they had a highly interdependent association with that person and felt that they should have been able to control his or her actions. In contrast, people felt ashamed for another's wrongdoing to the extent that they felt that the person's behavior was relevant to a social identity that they shared in common with the wrongdoer and appraised the other person's behavior as a negative reflection on themselves. In turn, each emotion predicted a unique behavioral response. Whereas guilt predicted a desire to make amends for another's wrongdoing, shame predicted a desire to distance oneself from the situation and the wrongdoer. Importantly, one's interpersonal bonds with a wrongdoer had little or no relation to how ashamed one felt for that person's behavior, and the degree to which the person's actions tarnished the group's reputation had little or no relation to feelings of guilt.

The research presented here advances our current understanding of shame and guilt as self-conscious emotions as well as our understanding of appraisals important in regulating 
intragroup and intergroup interactions. First, with respect to emotion theory, our studies represent the first systematic investigation of the appraisals that underlie why someone might feel ashamed versus guilty for the actions of others. Although other studies have explored how people respond to wrongs committed by fellow ingroup members (e.g. Doosje et al., 1998; McGarty et al., in press), our research is unique in its intent to map the terrain of vicarious shame and guilt in a way that is not tied to specific social associations or types of wrongdoing. Furthermore, our framework provides a platform for future research by describing vicarious shame and guilt at four levels of analyses: aspects of social association, self-related appraisals, emotional experience, and motivation.

It is also worth noting that this study represents some of the strongest evidence to date that shame and guilt are associated with distinct motivations. For example, even in groundbreaking work on the distinctions between these emotions, Tangney et al. (1996) did not find clear evidence that guilt included a greater desire to make amends for a personal wrongdoing than did shame. One possible reason for this lack of clarity is that past work has often measured distancing and repair as opposite ends of a single dimension, rather than as orthogonal motivations. Our data suggest that these may be very different motivations and should be studied independently.

In addition to advances in emotion research, the model presented here may also advance our understanding of the relationship of the self to the group. Most research on group behavior and perception has developed around one of two assumptions about the nature of groups. One set of theories has been developed for groups that are social categories defined largely by a shared characteristic or group label (e.g. Haslam et al., 2000; Park \& Judd, 1990; Turner, Hogg, Oakes, Reicher, \& Wetherell, 1987). A second set of theories has been developed for groups that are close interacting groups that are characterized as having high degrees of communication, cooperation, and mutual influence (Cartwright \& Zander, 1960; E. R.
Smith, Murphy, \& Coats, 1999; Levine \& Moreland, 1998). In our present work, we have conceptualized shared identity and interdependence as separate dimensions of social association rather than as mutually exclusive types of groups. Furthermore, the results show that articulating these dimensions of social association can have important implications for how members of groups perceive and respond to the behavior of their fellow ingroup members. To our knowledge, this is the first study to explicitly compare how these two dimensions of association predict intragroup and intergroup processes (but see Hamilton et al., 1998; Hogg \& Moreland, 1993; Sedikides, Schopler, \& Insko, 1998, for a discussion of the advantages of inclusive frameworks for studying groups).

\section{Limitations and future directions}

The study we presented relied on a narrative recall approach to studying emotion. The narrative approach has the benefit of assessing a wide variety of events that are personally meaningful to participants. Even so, this retrospective nature of this approach does limit some of the conclusions we can draw about causation and does not allow us to pull apart the temporal sequencing of these component processes. For this reason, we did not feel we could adequately test mediational hypotheses in these cross-sectional studies. Again experimental studies will be needed to test mediational claims and examine these emotions on-line.

In addition, we have constrained our analysis to events for which individuals have felt a fairly strong and memorable emotional reaction to another's behavior. Because of this, we are somewhat limited in drawing conclusions about what factors are necessary to experience an emotional reaction in the first place. We can speculate, however, that certain other appraisals are required to activate a vicarious shame or vicarious guilt experience. The first step, we believe, is that the individual assigns responsibility for the negative event to another individual with whom they are somehow associated. Second, the individual must perceive the event to be negative or discrepant with goals that he or she holds. Other factors, such as the 
intentionality of the act may also influence these initial appraisals and should be investigated in future work.

We believe that one important issue for future work will be to integrate what is known from the literature on people's affective reactions to the more global and historical wrongdoings (such as a history of colonialization) of their groups (e.g. Doosje et al., 1998; Iyer et al., 2003; McGarty et al., in press-for a recent edited volume on the topic see Branscombe \& Doojse, 2004) with other work on people's shame and guilt reaction to specific acts of ingroup members (e.g. Johns, Schmader, \& Lickel, in press; Schmader \& Lickel, in press). Clearly, our current framework is directed primarily toward explaining how people react to specific acts by other members of their group. Future work should compare how people make sense of specific acts (such as a White American observing another White American act in a racist way) with more global and historical events (such as the institutionalized history of racism in America). Nonetheless, we agree with the arguments of Iyer et al. (2003) that research on group-based guilt will be advanced most productively when researchers attempt to identify the importance of distinctions between guilt and other emotions, such as sympathy, shame, and anger. We believe that the framework we present in this paper is a useful step in this direction.

In addition to its applicability to situations that are typically the focus of social identity and intergroup relations research, we are also interested in the application of our framework to other settings such as workplace or intimacy groups. For example, parents clearly may be blamed for the actions of their children (e.g. Lickel, Schmader, \& Hamilton, 2003), but surprisingly little research has examined parents' emotional reactions to their children's transgressions. Likewise, in romantic relationships, feelings of vicarious shame and guilt for one's partner may play a role in predicting relationship satisfaction and duration. We believe that the findings reported here represent a starting point for these investigations.
In conclusion, shame and guilt are intriguing emotions that have only recently come under focused empirical inquiry. Likewise, investigations of how the self is shaped through group memberships have recently flourished. However, much of the recent work that has been done on how groups affect the self has focused on how groups impact more on cognitive processes of the self (e.g. Sedikides et al., 1998; E. R. Smith \& Henry, 1996). Less work has examined the impact of groups on the specific emotions that people experience. It is our hope that the framework developed here will encourage additional research that integrates theory on emotion and group processes.

\section{Acknowledgments}

This research was supported by a National Science Foundation Grant \#BCS-0112427 awarded to the first and second authors and a faculty small grant awarded to the second author from the University of Arizona Foundation.

We thank Greg Willard, Shawn Williams, Jonah Firestone, Heather Gangestad, Amy Baesler, Shawna Boggie, Jill Endres, Emily Bacal, Lorena Bravo, Chris Davis, Calli Payne, Jessica Pishney, Cynthia Wallentin, and Ali Winkler for their invaluable help with collecting and coding these datasets. We also wish to thank Shelly Gable, John Nezlak, and Tom Denson for their statistical advice and Mark Zanna, Jeff Greenberg, and Michael Johns for their comments on earlier versions of this paper.

\section{References}

Allport, G. W. (1954). The nature of prejudice. Cambridge, MA: Addison-Wesley.

Baumeister, R. F., Stillwell, A. M., \& Heatherton, T. F. (1995). Personal narratives about guilt: Role in action control and interpersonal relationships. Basic and Applied Social Psychology, 17, 173-198.

Branscombe, N. R., \& Doojse, B. (2004). Collective guilt: International perspectives. New York: Cambridge University Press.

Brewer, M. B. (2000). Superordinate goals versus superordinate identity as bases of intergroup cooperation. In D. Capozza \& R. Brown (Eds.), Social identity processes: Trends in theory and research (pp. 117-132). London, UK: Sage. 
Cartwright, D., \& Zander, A. (1960). Group dynamics. Evanston, IL: Row, Peterson.

Cialdini, R. B., \& de Nicholas, M. E. (1989). Self-presentation by association. Journal of Personality and Social Psychology, 57, 626-631.

Doojse, B., Branscombe, N. R., Spears, R., \& Manstead, A. S. R. (1998). Guilty by association: When one's group has a negative history. Journal of Personality and Social Psychology, 75, 872-886.

Eidelman, S., \& Biernat, M. (2003). Derogating black sheep: Individual or group protection? Journal of Experimental Social Psychology, 39, 602-609.

Eisenberg, N. (2000). Emotion, regulation, and moral development. Annual Review of Psychology, 51, 665-697.

Gaertner, L., \& Schopler, J. (1998). Perceived ingroup entitativity and intergroup bias: An interconnection of self and others. European Journal of Social Psychology, 28, 963-980.

Hamilton, D. L., Sherman, S. J., \& Lickel, B. (1998). Perceiving social groups: The importance of the entitativity continuum. In C. Sedikides,

J. Schopler, \& C. A. Insko (Eds.), Intergroup cognition and intergroup behavior (pp. 47-74). Mahwah, NJ: Erlbaum.

Haslam, N., Rothschild, L., \& Ernst, D. (2000). Essentialist beliefs about social categories. British Journal of Social Psychology, 39, 113-127.

Hatfield, E., Cacioppo, J. T., \& Rapson, R. L. (1994). Emotional contagion. New York: Cambridge University Press.

Hinsz, V. B., Tindale, R. S., \& Vollrath, D. A. (1997). The emerging conceptualization of groups as information processors. Psychological Bulletin, 121, 43-64.

Hirschfeld, L. A. (1995). Do children have a theory of race? Cognition, 54, 209-252.

Hogg, M. A., \& Moreland, R. L. (1993). Studying social processes in small groups. British Journal of Social Psychology, 32, 107-110.

Hong, Y., \& Chiu, C. (1992). A study of the comparative structure of guilt and shame in a Chinese society. Journal of Personality, 126, 171-179.

Iyer, A., Leach, C. W., \& Crosby, F. J. (2003). White guilt and racial compensation: The benefits and limits of self-focus. Personality and Social Psychology Bulletin, 29, 117-129.

Johns, M., Schmader, T., \& Lickel, B. (in press). Ashamed to be an American? The role of identification in predicting vicarious shame for anti-Arab prejudice after $9 / 11$. Self and Identity.

Keltner, D. (1995). The signs of appeasement: Evidence for the distinct displays of embarrassment, amusement, and shame. Journal of Personality and Social Psychology, 68, 441-454.

Keltner, D., \& Harker, L. (1998). The forms and functions of the nonverbal signal of shame. In P. Gilbert \& B. Andrew (Eds.), Shame: Interpersonal behavior, psychopathology, and culture. Series in affective science (pp. 78-98). London: Oxford University Press.

Krech, D., \& Crutchfield, R. C. (1948). Theory and problems of social psychology. New York: McGraw-Hill.

Levine, J. M., \& Moreland, R. L. (1998). Small groups. In D. T. Gilbert, S. T. Fiske, \& L. Gardner (Eds.), The handbook of social psychology (4th ed., Vol. 2, pp. 415-469). New York: McGraw-Hill.

Lewin, K. (1948). Resolving social conflicts. New York: Harper.

Lickel, B., Hamilton, D. L., Wieczorkowska, G., Lewis, A., Sherman, S. J., \& Uhles, A. N. (2000). Varieties of groups and the perception of group entitativity. Journal of Personality and Social Psychology, 78, 223-246.

Lickel, B., Schmader, T., \& Hamilton, D. L. (2003). A case of collective responsibility: Who else was to blame for the Columbine High School shootings? Personality and Social Psychology Bulletin, 29, 194-204.

Mackie, D. M., Devos, T., \& Smith, E. R. (1999). Intergroup emotions: Explaining offensive action tendencies in an intergroup context. Journal of Personality and Social Psychology, 79, 602-616.

Manstead, A. S., \& Tetlock, P. E. (1989). Cognitive appraisals and emotional experience: Further evidence. Cognition Eं Emotion, 3, 225-239.

Marques, J. M., Yzerbyt, V. Y., \& Leyens, J. P. (1988). The 'black sheep effect': Extremity of judgments towards ingroup members as a function of group identification. European Journal of Social Psychology, 18, 1-16.

McGarty, C., Pedersen, A., Leach, C. W., Mansell, T., Waller, J., \& Bliuc, A. M. (in press). Group-based guilt as a predictor of commitment to apology. British Journal of Social Psychology.

Miller, R. S. (1987). Empathic embarrassment: Situational and personal determinants of reactions to the embarrassment of another. Journal of Personality and Social Psychology, 53, 1061-1069.

Morris, H. (1987). Nonmoral guilt. In F. Schoeman (Ed.), Responsibility, character, and the emotions: New essays in moral psychology (pp. 220-240). New York: Cambridge University Press.

Niedenthal, P. M., Tangney, J. P., \& Gavanski, I. (1994). 'If only I weren't' versus 'If only I hadn't': Distinguishing shame and guilt in counterfactual 
thinking. Journal of Personality and Social Psychology, 67, 585-595.

Norton, M. I., Monin, B., Cooper, J., \& Hogg, M. A. (2003). Vicarious dissonance: Attitude change from the inconsistency of others. Journal of Personality and Social Psychology, 85, 47-62.

Ortony, A., Clore, G. L., \& Collins, A. (1988). The cognitive structure of emotions. New York: Cambridge University Press.

Park, B., \& Judd, C. M. (1990). Measures and models of perceived group variability. Journal of Personality and Social Psychology, 59, 173-191.

Prentice, D. A., Miller, D. T., \& Lightdale, J. R. (1994). Asymmetries in attachments to groups and their members: Distinguishing between commonidentity and common bond groups. Personality and Social Psychology Bulletin, 20, 484-493.

Rabbie, J. M., \& Horwitz, M. (1988). Categories versus groups as explanatory concepts in intergroup relations. European Journal of Social Psychology, 18, 117-123.

Raudenbush, S. W., Bryk, T., \& Congdon, R. (2000). HLM 5: Hierarchical linear and nonlinear modeling. Lincolnwood, IL: Scientific Software International.

Rothbart, M., \& Taylor, M. (1992). Category labels and social reality: Do we view social categories as natural kinds? In K. Fiedler \& G. R. Semin (Eds.), Language, interaction and social cognition (pp. 11-36), Newbury Park, CA: Sage.

Schlink, B. (1995). The reader. New York: Vintage International.

Schmader, T., \& Lickel, B. (in press). Stigma and shame: Emotional responses to the stereotypic actions of one's ethnic ingroup. In S. Levin \& C. van Laar (Eds.), Stigma and group inequality: Social psychological approaches, Mahwah, NJ: Erlbaum.

Sedikides, C., Schopler, J., \& Insko, C. A. (1998). Intergroup cognition and intergroup behavior. Mahwah, NJ: Erlbaum.

Smith, C. A., \& Ellsworth, P. C. (1985). Patterns of cognitive appraisal in emotion. Journal of Personality and Social Psychology, 48, 813-838.

Smith, E. R. (1993). Social identity and social emotions: Toward new conceptualizations of prejudice. In D. M. Mackie \& D. L. Hamilton (Eds.), Affect, cognition, and stereotyping: Interactive processes in group perception (pp. 297-315). San Diego, CA: Academic Press.

Smith, E. R., \& Henry, S. (1996). An in-group becomes part of the self: Response time evidence. Personality and Social Psychology Bulletin, 22, 635-642. Smith, E. R., Murphy, J., \& Coats, S. (1999).
Attachment to groups: Theory and management. Journal of Personality and Social Psychology, 77, 94-110.

Smith, R. H., Webster, J. M., Parrott, W. G., \& Eyre, H. L. (2002). The role of public exposure in moral and nonmoral shame and guilt. Journal of Personality and Social Psychology, 83, 138-159.

Stipek, D. (1998). Differences between Americans and Chinese in the circumstances evoking pride, shame, and guilt. Journal of Cross-Cultural Psychology, 29, 616-629.

Tajfel, H. (1970). Experiments in intergroup discrimination. Scientific American, 223, 96-102.

Tajfel, H., \& Turner, J. C. (1986). Social identity theory of intergroup behavior. In W. Austin \& S. Worchel (Eds.), Psychology of intergroup relations (2nd ed., pp. 7-24). Chicago: Nelson-Hall.

Tangney, J. P. (1995). Shame and guilt in interpersonal relationships. In J. Tangney \& K. W. Fischer (Eds.), Self-conscious emotions: The psychology of shame, guilt, embarrassment, and pride (pp. 114-139). New York: Guilford Press.

Tangney, J. P., \& Fischer, K. W. (1995). Self-conscious emotions. New York: Guilford.

Tangney, J. P., Miller, R. S., Flicker, L., \& Barlow, D. B. (1996). Are shame, guilt, and embarrassment distinct emotions? Journal of Personality and Social Psychology, 70, 1256-1269.

Tesser, A. (1988). Toward a self-evaluation maintenance model of social behavior. In L. Berkowitz (Ed.), Advances in experimental social psychology (Vol. 21, pp. 181-227). San Diegto, CA: Academic Press Inc.

Tönnies, F. (1988) [1887, 1935]. Community and society (Gemeinschaft und Gesellschaft). New Brunswick, NJ: Transaction Books.

Turner, J. C., Hogg, M. A., Oakes, P. J., Reicher, S. D., \& Wetherell, M. S. (1987). Rediscovering the social group: A self-categorization theory. Oxford, UK: Blackwell.

Weiner, B. (1986). An attributional theory of motivation and emotion. New York: Springer-Verlag.

Wicker, F. W., Payne, G. C., \& Morgan, R. D. (1983). Participant descriptions of guilt and shame. Motivation and Emotion, 7, 25-39.

Wilder, D., \& Simon, A. F. (1998). Categorical and dynamic groups: Implications for social perception and intergroup behavior. In C. Sedikides, J. Schopler, \& C. A. Insko (Eds.), Intergroup cognition and intergroup behavior (pp. 27-44). Mahwah, NJ: Erlbaum.

Yzerbyt, V. Y., Rocher, S., \& Schadron, G. (1997). Stereotypes as explanations: A subjective essentialistic view of group perception. In 
R. Spears, P. J. Oakes, N. Ellemers, \& S. A. Haslam (Eds.), The social psychology of stereotyping and group life (pp. 20-50). Oxford, UK: Blackwell.

Paper received 9 May 2004; revised version accepted 8 October 2004.

\section{Biographical notes}

BRIAN LICKEL is an assistant professor in the Department of Psychology at the University of Southern California. His work focuses on emotion and social cognition related to groups, in particular to folk theories of groups, social emotions such as shame and guilt, and the role of group-based responsibility in intergroup behavior.

TONI SCHMADER is Assistant Professor of Psychology at the University of Arizona. She received her $\mathrm{PhD}$ in social psychology from the University of California, Santa Barbara in 1999. Her research examines how individuals are affected by their social identities, particularly when those identities are targeted by negative social stereotypes.

MARCHELLE SCARNIER is a graduate student of Psychology at the University of Arizona. She received her MA in social psychology in 2003 and is currently working towards her PhD. Presently, her research examines the interplay between motivation and cognition processes when people strive to maintain positive perceptions of close others who confirm negative stereotypes.

MATHEW CURTIS is a graduate student in Psychology at the University of Southern California. His current research examines vicarious shame and guilt in close relationships, linguistic intergroup bias, and legal decision-making.

DANIEL AMES earned his PhD in social/personality psychology from UC Berkeley and is now an Assistant Professor at Columbia Business School. His research interests revolve around social judgments and behavior. 